\title{
ARTICLE
}

\section{Invisible before the law}

\section{The legal position of persons with intellectual disabilities under the Dutch Care and Compulsion Act (Wzd) in light of Article 12 of the Convention on the Rights of Persons with Disabilities (CRPD)}

\author{
F. Schuthof LLM*
}

\section{Introduction}

In December 2016, the Dutch newspaper Noord-Holland Nieuws reported on the case of Tamara, a 23-year-old woman with an intellectual disability. ${ }^{1}$ According to this article, Tamara had been placed in a closed care institution for several years without a justified reason. ${ }^{2}$ Unfortunately, Tamara's case is not an isolated incident. According to statements by the medical journal Medisch Contact and by Stichting Klokkenluiders Verstandelijk Gehandicapten - a foundation which unites whistle-blowers on the topic of disability care - numerous reports have emerged over the years that resemble this case. ${ }^{3}$ Moreover, studies show that the use of coercive measures in the mental health care sector has increased in the Netherlands during recent years. ${ }^{4}$ Taken together, these findings raise the question: what is the

* $\quad$ Fiore Schuthof conducts research into better empowerment and protection of the elderly as a PhD student at Utrecht University (UU).

1 According to the World Health Organization (WHO), 'intellectual disability' refers to 'a significantly reduced ability to understand new or complex information and to learn and apply new skills (impaired intelligence)'. See World Health Organization, Regional Office for Europe, 'Definition: intellectual disability' www.euro.who.int/en/health-topics/noncommunicable-diseases/mentalhealth/news/news/2010/15/childrens-right-to-family-life/definition-intellectual-disability accessed 17-6-2020.

2 Eline Boshuizen, 'Verstandelijk beperkte Tamara zat onterecht opgesloten in zorginstelling Philadelphia' Noord-Holland Nieuws (Amsterdam, 6 December 2016) www.nhnieuws.nl/nieuws/196598/verstandelijk-beperkte-tamara-zat-onterecht-opgesloten-in-zorginstelling-philadelphia\#. accessed 17-2-2020.

3 Ibid. and Brenda Frederiks, 'Brandon is meer dan een gevaar' Medisch Contact (Utrecht, 2 March 2011) www.medischcontact.nl/nieuws/laatste-nieuws/artikel/brandon-is-meer-dan-eengevaar.htm accessed 17-6-2020. See also the case of Jolanda Venema: Karin Sitalsing, 'Dertig jaar na Jolanda Venema kan er zoveel meer dan de vrijheid beperken' Trouw (Amsterdam, 12 March 2019) www.trouw.nl/nieuws/dertig-jaar-na-jolanda-venema-kan-er-zoveel-meer-dande-vrijheid-beperken b6db964a/ accessed 17-6-2020.

4 Jan Broer et al., 'Stijging van BOPZ-maatregelen en dwangopnames in de GGZ' (2018) 162(49) Nederlands Tijdschrift voor Geneeskunde 1, 1 and Editorial office Skipr, 'Snelste stijging aantal dwangmaatregelen ggz in 10 jaar', Skipr (Houten, 3 February 2020) www.skipr.nl/nieuws/snelstestijging-aantal-dwangmaatregelen-ggz-in-10-jaar/ accessed 17-6-2020. 
legal position of persons with intellectual disabilities in relation to involuntary care?

Within the context of human rights law, the rights of persons with intellectual disabilities are recognized in the Convention on the Rights of Persons with Disabilities (CRPD). ${ }^{5}$ A considerable amount of literature has examined the topic of involuntary care for persons with intellectual disabilities in light of this Convention. Among others, this subject has been analyzed in relation to the prohibition of torture and other cruel inhuman or degrading treatment or punishment (Art. 15 CRPD) ${ }^{6}$ the right to protection of a person's physical and mental integrity (Art. 17 CRPD) ${ }^{7}$ and the liberty and security of persons (Art. 14 CRPD). ${ }^{8}$

Little is known, however, about the relation between the use of involuntary care and Article 12 of the CRPD. This article, entitled 'equal recognition before the law', deals with the legal position of persons with intellectual disabilities. More specifically, it contains the obligation of states to recognize that persons with disabilities enjoy 'legal capacity' on an equal basis with others in all aspects of life. According to the monitoring body of the CRPD, the Committee on the Rights of Persons with Disabilities (hereafter: the Committee), this concept includes both legal standing, or the ability of all persons to hold rights and duties, as well as legal agency, referring to the possibility of individuals to exercise those rights in a legal system. ${ }^{9,10}$

Throughout history, various groups have been denied the right to make effective legal decisions because they lack legal capacity. ${ }^{11}$ For example, in medieval Europe, legal personhood was dependent on feudal roles and the clan membership of persons. Later, during the colonial period, slaves were described as 'three-fifths of a person' by the Constitution of the United States. In addition, in most Western legal

5 Persons with intellectual disabilities fall within the scope of this Convention. See Convention on the Rights of Persons with Disabilities (adopted 13 December 2006, entered into force 3 May 2008) 61 UNTS 106 (CRPD) art 1.

6 Tina Minkowitz, 'Recognizing forced and coerced psychiatric interventions against women, men and children as a harmful cultural practice' (2014) Center for the Human Rights of Users and Survivors of Psychiatry, Submission for Joint CEDAW-CRC General Recommendation/General Comment on Harmful Practices 1, 2 and Tina Minkowitz, 'The United Nations Convention on the Rights of Persons with Disabilities and the Right to Be Free from Nonconsensual Psychiatric Interventions' (2007) 34 Syracuse J. Int'l L. \& Com. 405, 417.

7 Tony Ward and Claire Stewart, 'Putting human rights into practice with people with an intellectual disability' (2008) 20(3) Journal of Developmental and Physical Disabilities 297-311 and Bernadette McSherry, 'Protecting the Integrity of the Person: Developing Limitations on Involuntary Treatment' (2008) 26 Law Context: A Socio-Legal J. 111-124.

8 Tina Minkowitz, 'Why Mental Health Laws Contravene the CRPD-An Application of Article 14 with Implications for the Obligations of States Parties' (2011) 1 SSRN https://papers.ssrn.com/ sol3/papers.cfm?abstract_id=1928600 accessed 17-6-2020. Patricia Gómez et al., 'Psychosocial Disability and Deprivation of Liberty: Reviewing the case of Qatar in the light of the Convention on the Rights of Persons with Disabilities' (2018) 24 International Journal of Mental Health and Capacity Law 55, 64. UN Committee on the Rights of Persons with Disabilities, 'Guidelines on the right to liberty and security of persons with disabilities' (2015) 14th session, 18.

9 The Committee has the competence to issue these General Comments as a result of Art. 39 of the CRPD.

10 Council of Europe, 'Who Gets to Decide? Right to Legal Capacity for Persons with Intellectual and Psychosocial Disabilities' (2012) CommDH Issue Paper 2, 7.

11 UN Committee on the Rights of Persons with Disabilities (CRPD), 'General Comment No. 1: Article 12: Equal recognition before the law' (19 May 2014) CRPD/C/GC/1 2. 
systems, women were not granted legal capacity until the twentieth century. ${ }^{12}$ Today, a person's legal capacity is no longer influenced by class, race or gender. ${ }^{13}$ Yet, it is still affected by the element of disability. As the Committee states: 'persons with disabilities remain the group whose legal capacity is most commonly denied in legal systems worldwide. ${ }^{.14}$

Why is the recognition of a person's legal capacity relevant? According to psychologist Bruce Winck, one of the side effects of a denial of legal capacity is an associated label of incompetence. This is because the concept of legal capacity is often interpreted in relation to the mental capacity of individuals to make decisions. ${ }^{15} \mathrm{Such}$ a label of incompetence may, as Winck states, result in a self-fulfilling prophecy. Namely, without the chance to carry out certain acts, individuals will not be able to establish the capabilities that are needed to fulfil these acts. ${ }^{16}$ Furthermore, a denial of legal capacity will restrict other human rights, such as the right to marry, the right to vote and the right to private and family life. In order for these rights to become legally effective, legal capacity is required..$^{17}$ It is a common practice of states to strip persons with intellectual and other disabilities of their legal capacity. Moreover, a lack of this capacity is often used to justify the use of involuntary care for these individuals. ${ }^{18}$ This may pave the way for situations of abuse, as persons without legal capacity become 'powerless'. ${ }^{19}$

In the Netherlands, a new law that is related to involuntary treatment came into force in January 2020, called the 'Care and Compulsion Act' (Dutch: Wet Zorg en Dwang (Wzd)). This highlights the need for fresh insight into the legal position of Dutch persons with intellectual disabilities with respect to the issue of involuntary treatment. Consequently, the main question that this article strives to answer is: what is the legal position of persons with intellectual disabilities under the Wzd in light of Article 12 of the CRPD?

The overall structure of this study is divided into four parts. The first part begins by defining the core term 'disability'. It then moves on to describe the human rights norms of Article 12 CRPD and the way in which these norms have been interpreted

12 Eilionóir Flynn and Anna Arstein-Kerslake, 'Legislating personhood: Realising the right to support in exercising legal capacity' (2014) 10(1) International Journal of Law in Context 81, 81.

13 Here, reference is made to Western legal systems. In Arab law, however, some scholars argue that the legal capacity of women remains restricted during menstruation, pregnancy and post-natal periods. See Mahdi Zahraa, 'The Legal Capacity of Women in Islamic Law' (1996) 11 Arab L.Q. 245, 262.

14 CRPD, ‘General Comment No. 1' 2.

15 UN Committee on the Rights of Persons with Disabilities, 'General Comment No. 1. Article 12: Equal Recognition before the law' (2014), 4.

16 Bruce J. Winick, 'The Side Effects of Incompetency Labeling and the Implications for Mental Health' (1995) 1(1) PSYCH. PUB. POL'Y \& L. 6, 10-11 in: Amita Dhanda, 'Legal capacity in the disability rights convention: stranglehold of the past or lodestar for the future' (2006) 34 Syracuse J. Int'l L. \& Com. 429, 436.

17 Council of Europe, 'Who Gets to Decide? Right to Legal Capacity for Persons with Intellectual and Psychosocial Disabilities' (2012) CommDH Issue Paper 2, 7-8.

18 United Nations Human Rights Council, 'Report of the Special Rapporteur on torture and other cruel, inhuman or degrading treatment or punishment, Juan E. Méndez' (1 February 2013) A/ $\mathrm{HRC} / 22 / 53$ 7, 15.

19 United Nations Human Rights Council, 'Interim report of the Special Rapporteur on torture and other cruel, inhuman or degrading treatment or punishment' (28 July 2008) A/63/175 11. 
by scholars in the field of disability law. The third part analyzes the Dutch Wzd as a case study, exploring how the international human rights norms of Article 12 CRPD are implemented in a national legal framework. Finally, this article presents several recommendations in the conclusion that may bring the Wzd into closer alignment with Article 12 CRPD.

\section{Theorizing 'disability'}

In Western societies, the public attitudes towards the legal position of persons with disabilities have varied over time. In particular, these attitudes reveal themselves in the way in which the term 'disability' has been defined. ${ }^{20}$ Until the 1970 s, the main point of reference for defining disability in the West was the 'medical model'. In this model, disability is viewed as a medical phenomenon that needs to be cured, seeing that persons with disabilities are unable to function within society. ${ }^{21}$ This group therefore needed to be sheltered and protected by medical practitioners. ${ }^{22}$ In the context of contemporary political thought, a notable example of the medical model of disability is reflected in the work of political philosopher John Rawls. ${ }^{23}$ Rawls follows this model by seeing disability as a natural phenomenon and by describing persons with disabilities as 'hard cases', who 'distract our moral perception by leading us to think of people distant from us whose fate arouses pity and anxiety'. ${ }^{2425}$ According to this philosopher, focus should be placed on persons who 'can be a citizen, that is, a normal and fully cooperating member of society over a complete life'. ${ }^{26}$ On the political level, the medical model led to policies of segregation and institutionalization which lasted until the second half of the twentieth century. ${ }^{27}$ Subsequently, throughout the twentieth century, this group has been denied several basic human rights, including the right to marry, to have children, to vote and to refuse treatment. ${ }^{28}$

20 Michael Baffoe, 'Stigma, discrimination \& marginalization: Gateways to oppression of persons with disabilities in Ghana, West Africa' (2013) 3(1) Journal of Educational and Social Research 187, 188-189.

21 Justin A. Haegele et al., 'Disability discourse: Overview and critiques of the medical and social models' (2016) 68(2) Quest 193, 195.

22 Theresia Degener, 'A human rights model of disability' (2014) Disability social rights 1, 3-4.

23 Harry Brighouse, 'Can Justice as Fairness Accommodate the Disabled?' (2001) 27(4) Social Theory and Practice 537, 537. See also Christopher A. Riddle, Disability and justice: The capabilities approach in practice (Lexington Books, 2014) 1 and Linda Barclay, 'Disability, Respect and Justice' (2010) 27(2) Journal of Applied Philosophy 154-171.

24 On the relation between the medical model and the work of John Rawls, see Barbara Arneil and Nany J. Hirschmann, Disability and political theory (Cambridge University Press, 2016) 88.

25 John Rawls, 'A Kantian Concept of Equality' (1975) Cambridge Review 96. See also John Rawls 'Justice as Fairness: Political Not Metaphysical' (1985) 14 PHIL. \& PUB. AFF. 223.

26 John Rawls, Political liberalism (Columbia University Press, 1993) 18.

27 Kristin Booth Glen, 'Changing Paradigms: Mental Capacity, Legal Capacity Guardianship, and Beyond’ (2012) 44 Colum Hum Rts L Rev 93, 104.

28 Booth Glen, 'Changing Paradigms' 105 and Baffoe, 'Stigma, discrimination \& marginalization' 188-189. 
From the 1970s onwards, the perception of the medical model has been heavily critiqued by the disability rights movement that had emerged a decade earlier. ${ }^{29}$ Scholars and activists argued for a 'social model of disability', in which disability is not only seen in terms of a medical impairment, but also in relation to the barriers in the environments of persons. ${ }^{30}$ Disability, then, exists because of labelling and cultural representations of human differences. ${ }^{31}$

The social model also gives attention to the individual perception of disability. Within this approach, a person is actually disabled if that person cannot be or do the things he or she wants. ${ }^{32}$ The advantage of taking into account this subjective dimension of disability is that it takes into consideration the diversity of individuals. ${ }^{33}$ An understanding of this diversity may offer a person growth in skills that are most important to him or her. ${ }^{34}$ For example, two persons with the same mental impairment and practical opportunities might still suffer to a different extent from the stigma that is associated with that impairment. In addition, these individuals might cope with their disability in different ways.

The social model was used as the primary philosophical basis during the negotiations of the CRPD at the beginning of the twenty-first century. ${ }^{35}$ When viewing the social model in light of the CRPD at present, several similarities can be observed. First, both the social model and the CRPD do not interpret the term 'disability' solely by reference to a person's medical deficiency. In the view of this Convention, a person is disabled when the barriers within the interaction between an individual and its environment restrict the societal participation of that person. ${ }^{36}$ Put differently, the CRPD focuses on discriminatory policies for explaining disability. ${ }^{37}$ Second, both the social model and the CRPD emphasize the unique will and preferences of persons, in the sense that they are the placed at the centre of the decisions that apply to them..$^{38}$ At the heart of this focus lies Article 12 of the CRPD, which

29 See, among others, Martha Nussbaum, Frontiers of justice. Disability, nationality, species membership (Cambridge: Belknap Press, 2006), Brian M. Barry, Justice as impartiality (New York: Oxford University Press, 1995), Gerald A. Cohen, Self-ownership, freedom, and equality (Cambridge University Press, 1995) and Eva F. Kittay, Love's labor. Essays on women, equality and dependency (Routledge, 1999).

30 Arneil, Disability and Political Theory 88.

31 Dimitris Anastasiou and James M. Kauffman, "The social model of disability: Dichotomy between impairment and disability' (2013) 38(4) The Journal of Medicine and Philosophy: A forum for bioethics and philosophy of medicine 450.

32 Sophie Mitra, 'The capability approach and disability' (2006) 16(4) Journal of disability policy studies 236, 241.

33 Lorella Terzi, 'Beyond the dilemma of difference: The capability approach to disability and special educational needs' (2005) 29(3) Journal of Philosophy of Education 443, 452.

34 Giampiero Griffo, 'Models of disability, ideas of justice, and the challenge of full participation' (2014) 19(2) Modern Italy 147, 153.

35 Theresia Degener, 'Disability in a human rights context' (2016) 5(3) Laws 3. See also Anne Waldschmidt, 'Disability Goes Cultural' (2017) Culture-Theory-Disability 19, 21.

36 CRPD, preamble.

37 Theresia Degener, 'Challenges and Compliance of the UN CRPD', in Dotorthy Estrada-Tanck (ed.), Human Rights of Persons with Disabilities in International and EU Law (AEL Working Papers 2016) 3.

38 Agustina Palacios, 'The social model in the international convention on the rights of persons with disabilities' (2015) 4 The Age of Human Rights Journal 91, 95. 
contains the right to equal recognition before the law of persons with disabilities. The following section will move on to examine this article more closely.

\section{The paradigm shift of Article 12 CRPD}

The right to make effective legal decisions is contained in Article 12 of the Convention on the Rights of Persons with Disabilities (CRPD). Many scholars have suggested that Article 12 CRPD has brought about a 'paradigm shift' in the way we think about persons with disabilities. ${ }^{39}$ For this, reference is made to the way in which the Committee of this Convention describes 'incapacity' as a social construct, confirms the legal capacity of every person and denounces substitute decision-making in General Comment no. 1. ${ }^{40}$ This section seeks to analyze Article 12 CRPD in order to understand the specific legal obligations that the Netherlands is under.

\subsection{Personality, capacity and ability}

The first paragraph of Article 12 CRPD reaffirms the right of persons with disabilities to recognition everywhere as persons before the law. In the General Comment, the Committee explains that this recognition leads to 'legal personality'. ${ }^{41}$ This concept refers to the right of an individual to have his or her rights and duties recognized before the law. ${ }^{42}$ Consequently, when a person with a disability is for example refused to be registered at birth or denied an identity document, Article 12(1) CRPD would be violated. ${ }^{43}$ In practice, an individual who is recognized as a person before the law might still be denied legal capacity, due to a restrictive law or the appointment of a representative. ${ }^{44}$ In an effort to counter the denial of this right on the basis of disability, paragraph 2 of this Article moves on to stipulate the right to legal capacity 'on an equal basis with others in all aspects of life'.

39 Kees Blankman and Karen Vermariën, 'Conformiteit van het VN-Verdrag inzake de rechten van personen met een handicap en het EVRM met de huidige en voorgestelde wetgeving inzake vertegenwoordiging van wilsonbekwame personen in Nederland' (2015) 13, CRPD, 'General Comment No. 1' 5, Robert Dinerstein, 'Implementing legal capacity under article 12 of the UN convention on the rights of persons with disabilities: the difficult road from guardianship to supported decision-making' (2012) 19(2) Human Rights Brief 1, Booth Glen, 'Changing Paradigms' 93 and Michael Bach and Lana Kerzner, 'A new paradigm for protecting autonomy and the right to legal capacity' (2014) The Law Commission of Ontario http://repositoriocdpd.net:8080/bitstream/ handle/123456789/449/L_BachM_NewParadigmAutonomy_2010.pdf?sequence=1 accessed 226-2020.

40 Booth Glen, 'Changing paradigms' 98.

41 CRPD, 'General Comment No. 1' 3.

42 Lucy Series and Anna Nilsson, 'Article 12 CRPD: Equal Recognition before the Law' in Ilias Bantekas, Michael Ashley Stein and Dimitris Anastasiou (eds.) The UN Convention on the Rights of Persons with Disabilities: A Commentary (Oxford University Press, 2018) 10. See also Arlene S. Kanter, The development of disability rights under international law: From charity to human rights (Routledge, 2014) 236.

43 Series, 'Article 12 CRPD' 10 and Kanter, The development of disability rights 236. For example, the Committee observed that a group of Peruvian persons with disabilities had never received any identity cards. See UN Committee on the Rights of Persons with Disabilities, 'Concluding Observations on Peru' CRPD/C/PER/CO/1 (20 April 2012) par. 23. 
According to the Committee, individuals with disabilities are often denied their right to legal capacity by reference to deficiencies in their mental capacity. ${ }^{45}$ This phenomenon is particularly prevalent in the context of healthcare, where the possibility to refuse treatment is dependent on an examination of a person's mental abilities. ${ }^{46}$ However, the Committee asserts that the legal capacity of a person comprises a right that is granted 'by virtue of being human'. This right should not be related to a person's decision-making skills, particularly because these skills, according to the Committee, cannot be examined objectively. ${ }^{47} \mathrm{~A}$ distinction between these two concepts - legal capacity and mental capacity - is therefore important to ensure that the right to legal capacity will not be denied to persons with disabilities.

Within the academic debate, this distinction has been described as being 'impractical' and 'unrealistic'. ${ }^{48}$ For example, psychiatrist John Dawson highlights the usefulness of relating a person's mental capacity to his or her legal capacity, seeing that mental capacity tests help the State at a practical level to determine when it should intervene and when it should abstain from doing so. ${ }^{49}$ In the same vein, Alex Ruck Keene et al. argue that most judges in the United Kingdom depend on mental capacity assessments for identifying the support that individuals may need to exercise their legal capacity. ${ }^{50}$ In this regard, mental capacity can be viewed as a component of legal capacity, as it allows for the provision of support for persons with impaired decision-making skills.

Other scholars, including Clíona de Bhailís and Eilionóir Flynn, share the view of the Committee that mental capacity assessments are discriminatory in nature. In this regard, these scholars write that these tests 'hold persons with disabilities to a higher standard in decision-making than the rest of the population'. ${ }^{51}$ Similarly, having analyzed the case law of the United Kingdom, Gooding and Flynn note that several judges appear to have interpreted the definition of capacity in such a way as to achieve their desired outcome. ${ }^{52}$

Taken together, some scholars warn against the normative judgements on which mental capacity tests are based, arguing that they are subjective and discriminatory towards persons with disabilities. Others, however, point towards the practical relevance of these assessments for protecting vulnerable individuals. I would argue

46 Ibid.

47 Mitra, 'The capability approach and disability' 237.

48 Piers Gooding, "Navigating the "flashing amber lights" of the right to legal capacity in the united nations convention on the rights of persons with disabilities: Responding to major concerns' (2015) 15(1) Human Rights Law Review 45, 60.

49 Clíona de Bhailís and Eilionóir Flynn, 'Recognising legal capacity: commentary and analysis of Article 12 CRPD' (2017) 13(1) International Journal of Law in Context 20.

50 Alex Ruck Keene et al., 'Taking capacity seriously? Ten years of mental capacity disputes before England's Court of Protection' (2019) 62 International journal of law and psychiatry 56, 71. See also Canadian Association for Community Living (CACL), 'Response to Draft General Comment 1 on Article 12' (2014) www.ohchr.org/Documents/HRBodies/CRPD/GC/CanadianAssociationCommu nityLiving_Ar12.doc last accessed 22-6-2020.

51 De Bhailís, 'recognising legal capacity' 12.

52 Piers Gooding and Eilionóir Flynn, 'Querying the call to introduce mental capacity testing to mental health law: Does the doctrine of necessity provide an alternative?' (2015) 4(2) Laws 245, 255. 
that mental capacity assessments could be used to identify individuals who require support with decision-making. Important in this respect is that the concept of mental capacity should be clearly defined in the law as to avoid diverging and subjective interpretations of this term. Still, the mental capacity of a person should not have a bearing on his or her legal capacity. An inclusive society grants the right to this capacity to all citizens, including to individuals with disabilities.

\section{2 'Supported' instead of 'substituted' decision-making}

If a person with a disability has difficulty with exercising his or her legal capacity, he or she has the right to access support in this regard. This right is stipulated in Article 12(3) CRPD. The General Comment upholds that this support must be based on 'supported decision-making', rather than on 'substituted decision-making' ${ }^{53}$ In the latter, decisions are made for persons by for example mental health tribunals, psychiatrists or social workers. ${ }^{54}$ These decision-makers base their decision on what they perceive as being 'in the best interest' of these persons. ${ }^{55}$ The use of this best interest consideration is problematic as it is often motivated by the beliefs of the substitute decision-makers, rather than by the persons involved. ${ }^{56}$ Contrastingly, under supported decision-making regimes, decisions are made with persons, respecting their 'rights, will and preferences' as much as possible. ${ }^{57}$ These regimes are focused on the autonomy of individuals. The importance of supported decision-making is shown in a study by the European Agency for Fundamental Rights (FRA). This study found that individuals who were allowed to participate in the decisions regarding their placement in care institutions, described this process more positively compared to individuals whose decisions were made by others. ${ }^{58}$

\subsection{Protecting the exercise of legal capacity}

Paragraph 4 of Article 12 CRPD obliges States Parties to put in place safeguards with respect to the exercise of legal capacity for persons with disabilities. More specifically, this article outlines several requirements of these safeguards: they need to be proportional, free of conflict of interest and undue influence and they should apply within the shortest possible timeframe. Finally, impartial judicial bodies should review these safeguards regularly. ${ }^{59}$

What do these requirements entail? As to the element of 'proportionality', Stavros Tsakyrakis states that three questions need to be answered in the affirmative: (1)

CRPD, 'General Comment No. 1' 7-8.

Gooding, 'Querying the call' 248-249.

CRPD, 'General Comment No. 1' 6.

Remarkably, the best interest consideration is described as being of chief importance for all activities concerning children in Art. 3(1) of the Convention on the Rights of the Child (CRC). See Convention on the Rights of the Child (adopted 20 November 1989, entered into force 2 September 1990) 1577 UNTS 3 (CRC) Art 3(1). Some scholars argue that this concept is 'child-specific' in the sense that it plays an important role in enhancing the interests of children. See Eva Brems, Ellen Desmet and Wouter Vandenhole (eds.), Children's Rights Law in the Global Human Rights Landscape: Isolation, Inspiration, Integration? (Taylor \& Francis, 2017) 4.

CRPD, 'General Comment No. 1' 4.

Morten Kjaerum, 'Involuntary placement and involuntary treatment of persons with mental health problems', European Agency for Fundamental Rights (Luxembourg, 2012) 42.

59 CRPD, 'General Comment No. 1' 5. 
Is this measure suitable for the achievement of its purpose? (2) Is it necessary to achieve that purpose? And (3) do the benefits of this measure outweigh the possible burden for the individual in question? ${ }^{60}$

A 'conflict of interest' refers to a situation in which the view of a support person and an external party clash. This could for example be the case when a support person of an individual with a disability challenges the decision of a court or a care institution to apply treatment to that person. According to the Committee, the main point of reference in these situations should be to guarantee an adherence to the rights, will and preferences of individuals with disabilities. ${ }^{61}$

The requirement of Article 12(4) CRPD to establish safeguards that are free from undue influence is related by the Committee to situations 'where the quality of the interaction between the support person and the person being supported includes signs of fear, aggression, threat, deception or manipulation'. ${ }^{62}$ But which signs of fear or deception are determinative for defining influence as undue?

Similarly, the Committee does not define the duration and the review requirement. ${ }^{63}$ Further research is therefore needed to examine the availability of safeguards at the national level, as well as ways in which these safeguards can be implemented. The aim of the next section is to contribute to our understanding of this topic, by taking a closer look at the way in which the Netherlands follows the legal obligations that Article 12 CRPD sets out.

\section{The Dutch Care and Compulsion Act in relation to Article 12 CRPD}

On 13 July 2016, the Netherlands ratified the Convention on the Rights of Persons with Disabilities (CRPD). In doing so, it agreed to be bound by the obligation to evaluate and change national laws that are not in line with the articles of this Convention. ${ }^{6465}$ According to the Committee, the issue of involuntary treatment constitutes one of the legal areas which requires such evaluation. ${ }^{66}$ In the case of the Netherlands, the legislation that is closely connected to this topic is the Care and Compulsion Act $(W z d)$, which applies to persons with intellectual disabilities and dementia. ${ }^{67}$

60 Stavros Tsakyrakis, 'Proportionality: An assault on human rights?' (2009) 7(3) International Journal of Constitutional Law 468, 474.

61 CRPD, 'General Comment No. 1' 5.

62 Ibid.

63 Ibid.

64 CRPD, Art. 4(1)(a) and (b).

65 It is important to note that upon ratification, the Dutch government made multiple interpretative declarations in relation to Arts. 10, 12, 14, 15, 23, 25 and 29. See United Nations Treaty Collection, 'Convention on the Rights of the Child' https://treaties.un.org/Pages/ViewDetails. aspx?src=IND\&mtdsg_no=IV-11\&chapter=4\&clang=_en accessed 22-6-2020.

66 United Nations Committee on the Rights of Persons with Disabilities, 'Concluding Observations of the Committee on the Rights of Persons with Disabilities (Australia)' (2013) CRPD/C/AUS/ $\mathrm{CO} / 12-3$.

67 Wet zorg en dwang psychogeriatrische en verstandelijke gehandicapte cliënten (Wzd) 1 January 2020 (Care and Coercion Act). The issue of involuntary treatment is also covered by the Compulsory Mental Health Act (Dutch: Wvggz). This Act focuses on persons with mental disorders. 
The previous section outlined the legal norms of Article 12 CRPD. This section will now move on to apply this international human rights framework to the national level. The following questions will be tackled:

1 Does the Wzd recognize persons with disabilities as persons before the law?

2 Does the Wzd recognize the legal capacity of persons with disabilities on an equal basis with others in all aspects of life? Furthermore, does it follow the call of the Committee to make a distinction between legal capacity and mental capacity?

3 Has the Netherlands taken appropriate measures to provide access for persons with disabilities to the support that they may require in exercising their legal capacity? Are these measures aimed at making decisions with rather than for individuals, all the while respecting their rights, will and preferences as much as possible?

4 Has the Netherlands provided safeguards to prevent abuse in relation to the exercise of legal capacity? More specifically, has the Government put in place safeguards that are proportional, free of conflict of interest and undue influence? Do these measures apply within the shortest possible timeframe? And are these measures subject to regular review by an impartial judicial body?

\subsection{Recognition as persons before the law}

Returning to Article 12(1) CRPD, the question that needs to be raised is: does the Wzd recognize individuals with intellectual disabilities as persons before the law? Relevant in this respect is Article 3(1) Wzd, which specifies that decisions about the care of clients are to be taken by the clients themselves. ${ }^{68}$ In addition, the Wzd is premised on the right to self-determination. ${ }^{69}$ This right refers to an emphasis on the autonomy of individuals over any decisions with respect to their bodies. In other words, the starting point of the Wzd is that individuals with intellectual disabilities possess legal personality and that they are able to make decisions.

\subsection{Recognition of legal capacity}

As paragraph 2 of Article 12 CRPD sets forth: States Parties are under the obligation to recognize the legal capacity of persons with disabilities on an equal basis with others in all aspects of life. Moreover, States Parties are urged by the Committee to make a distinction between 'legal capacity' and 'mental capacity.'

An analysis of the Wzd reveals that this right is not absolute for persons with intellectual disabilities. If a person with an intellectual disability is unable to make a 'reasonable judgement of his or her interests in a certain situation', that individual is deemed 'mentally incapacitated' (Dutch: wilsonbekwaam).$^{70}$ In that case, his or her legal capacity is automatically restricted. ${ }^{71}$ Problematic in this respect is that

Wzd, Art. 3(1). See also Eerste Kamer der Staten-Generaal, 'Brief van de staatssecretaris van volksgezondheid, welzijn en sport. Regels ten aanzien van zorg en dwang voor personen met een psychogeriatrische aandoening of een verstandelijke handicap (Wet zorg en dwang psychogeriatrische en verstandelijk gehandicapte cliënten)' (5 October 2013) 31 996, 67. 
the Wzd does not provide an explanation of the term 'mental capacity'. As a result, it seems that this term has been interpreted in diverse ways in practice. For example, a study among caregivers working in Dutch treatment centres for persons with intellectual disabilities points out that no uniform policy exists among these centres regarding the assessment of mental capacity. ${ }^{72}$ These findings seem to support the concerns that were raised about the subjectivity of mental capacity assessments by the Committee as well as by Gooding, de Bhailís and Flynn.

On account of Article 3(2) Wzd, the assessment of this capacity is to be made by a medical practitioner (Dutch: Wzd-functionaris) who is in no way affiliated with the person in question. ${ }^{73}$ This regulation has been challenged by caregivers during the execution of several Wzd-pilot programmes in care institutions in 2019. A common response among these caregivers was: how is it possible for a medical practitioner who is not involved with a client to assess his or her mental capacity? ${ }^{74}$ This capacity can only rightfully be tested when the assessors are in close contact with the persons concerned. ${ }^{75}$ Only then will the unique differences that exist between persons with intellectual disabilities become apparent. For example, two persons might have the same IQ score of 55, but may still show differences in adaptive behavioural skills. Moreover, the impaired behavioural skills of a person might not be clearly visible if he or she has an IQ score of 70. In these cases, mental capacity can only be determined if an assessor becomes familiar with a person's unique particularities. ${ }^{76}$

Overall, this section explained that the Wzd does not recognize the right to legal capacity of persons with intellectual disabilities at all times. After a mental capacity test, the right of this group to make their own decisions can be restricted. This observation is not in line with Article 12(2) CRPD as well as with the call of the Committee to prohibit a denial of legal capacity by referring to a person's mental abilities. Still, as Ruck Keene et al. argue: mental capacity assessments can be viewed as a way to identify the individuals who require support with exercising their legal capacity. ${ }^{77}$ The Netherlands is obliged to provide this support to persons with intellectual disabilities on account of Article 12(3) CRPD. The next section will apply the human rights norms of this provision to the Wzd.

\subsection{The provision of support to exercise legal capacity}

Under the Wzd, persons may be supported by legal representatives to exercise legal capacity. This may be a person who is authorized by a client to act in his or her van 12-18 jaar met een lichte verstandelijke beperking in een OBC: een verkenning' (2013) 39(4) NTZ 269-277.

73 Wzd, Art. 3(2) and Art. 1(1)(m).

74 Lieke van de Camp et al., 'Wet Zorg en Dwang, Inzichten uit de pilots en droogoefensessies' Ministerie van Volksgezondheid, Welzijn en Sport (10 December 2019) 17.

75 Nederlandse Vereniging van Artsen voor Verstandelijk Gehandicapten (NVAVG), 'Medische beslissingen rond het levenseinde bij mensen met een verstandelijke beperking' (2007) 7 https:// nvavg.nl/wp-content/uploads/2014/upload/standaarden/medische-beslissingen-rond-het-

76 Ibid. levenseinde---def.pdf accessed 27-6-2020

77 Keene et al., 'Taking capacity seriously?' 71. 
place, or if this person is missing, a spouse or registered partner of a client, or if this person is missing, a parent, child, brother, sister, grandparent or grandchild of a client. ${ }^{78}$ Three types of legal representation exist under Dutch law. These types, ranging from mild to severe in terms of protection, include mentorship (Dutch: mentorschap), protective administration (Dutch: bewindvoering) and curatorship (Dutch: curatele). ${ }^{79}$ Mentors have authority over personal affairs, which includes decisions regarding care and treatment. Protective administrators look after the financial issues of individuals. Curators, finally, focus on all the interests of an individual - be it personal or financial. ${ }^{80}$

Persons with intellectual disabilities can face a full loss of legal capacity when they are placed under curatorship. The Dutch Civil Code (Dutch: Burgerlijk Wetboek $(B W))$ describes these persons as being 'legally incapacitated' (Dutch: handelingsonbekwaam).$^{81}$ In these cases, the curator acts as a substitute decision-maker regarding all the affairs of a person that are not related to healthcare. ${ }^{82}$ The intention of this legal representation system is to protect vulnerable individuals who are unable to take care of themselves or to promote their own interests. ${ }^{83}$ However, the intrusive nature of curatorship does not match reality. On a given day, an individual with an intellectual disability might find it difficult to find an apartment and sign a rental contract. In that case, support with decision-making may be beneficial. Nonetheless, he or she might still be competent to voice an opinion about which apartment to rent. A person who is appointed a curator, however, could even lose his or her right to make this decision.

Still, a less intrusive possibility than curatorship is available for persons who are in need of considerable support with decision-making. Dutch law allows for a combination of protective administration and mentorship. Whereas this measure is able to offer the same amount of protection to individuals as curatorship does, it does not lead to a complete denial of legal capacity. ${ }^{84}$ Another possibility for persons with intellectual disabilities in this regard is to create a voluntary 'living will', in which persons can give the authority to attorneys to act in a future period of inca-

82 Art. 1:381(2) of the Dutch Civil Code specifies that the legal capacity of persons under curatorship is completely taken away, except when the law stipulates otherwise. The Wzd stipulates otherwise by stating that the legal capacity of persons can only be limited when they are mentally incapacitated (wilsonbekwaam). See Wzd, Art. 3(2).

83 WODC, 'Werking Wet' 1.

84 Kees Blankman et al., 'Mentorschap in Perspectief' Ministerie van Volksgezondheid, Welzijn en Sport (2007) 11. 
pacity. ${ }^{85}$ These points further underpin the argument to put an end to the regime of curatorship. ${ }^{86}$

Article 3(2) of the Wzd stipulates that mentors, protective administrators and curators act in two instances: when they are a legal representative or when their client is deemed mentally incapacitated. ${ }^{87}$ The explanatory memorandum to the Wzd clarifies that legal representatives are solely authorized to act in the second instance - when a client is mentally incapacitated. ${ }^{88}$ Nonetheless, there is a high risk that Article 3(2) Wzd will be interpreted by mentors, protective administrators and curators in a different way. The phrasing of Article 3(2) Wzd suggests that legal representatives are allowed to act in the place of clients even when it is not established that a client is mentally incapacitated. ${ }^{89}$ In that case, mentally capable clients would only be able to exercise their legal capacity with the permission of their legal representative. ${ }^{90}$ It does not seem necessary to support persons with decision-making if they have full mental capacity. However, the phrasing of this article seems to permit representatives to act in all instances.

\subsection{Replacing 'substituted' with 'supported' decision-making}

In relation to Article 12(3) CRPD, the Committee has also pointed out that the support to exercise legal capacity should take the form of 'supported decision-making', as opposed to 'substituted decision-making'. In a submission to the Committee, the Dutch Government explained that it will continue to allow legal representation that takes the form of substituted decision-making, provided it is a measure of last resort. ${ }^{91}$ In this regard, Stelma, Blankman and Antokolskaia examined the frequency of the appointment of mentors, protective administrators and curators in the Netherlands in 2015. Their study reveals that these measures 'still seem to be the norm, rather than the exception'. ${ }^{92}$ This finding can be explained by the fact that in the Netherlands, there is no legal obligation for courts to assess whether less intrusive alternatives to legal representation are available. ${ }^{93}$ Considering the obligation that Article 12(3) CRPD sets out, to what extent does the Wzd reflect

Rieneke Stelma-Roorda, Kees Blankman and Masha V. Antokolskaia, 'A changing paradigm of protection of vulnerable adults and its implications for the Netherlands' (2019) Family \& Law 1, 10.

86 Rudolf B. Minderaa, Zorg voor mensen met een verstandelijke handicap (Uitgeverij Van Gorcum, 1997), 369.

87 Wzd, Art. 3(2) and Blankman, 'Conformiteit van het VN-Verdrag' 9.

88 Ministerie van Volksgezondheid, Welzijn en Sport, 'Integrale artikelsgewijze toelichting Wet zorg en dwang' 13.

89 Gezondheidsraad, 'Goede vertegenwoordiging' 8 (2019) 19.

90 Ibid. Strikingly, the Wvggz explicitly states that legal representatives are only authorized to act when a client is mentally incapacitated. See Wvggz, Art 1:3(3)(b).

91 United Nations Treaty Collection, 'Convention on the Rights of Persons with Disabilities' https:// treaties.un.org/Pages/ViewDetails.aspx?src=IND\&mtdsg_no=IV-15\&chapter=4\#EndDec accessed 14 April 2020.

92 Stelma-Roorda, Blankman and Antokolskaia, 'A changing paradigm' 9. See also De Rechtspraak, 'Weer meer mensen onder bewind' (2017) www.rechtspraak.nl/Organisatie-en-contact/ Organisatie/Raad-voor-de-rechtspraak/Nieuws/Paginas/Weer-meer-mensen-onder-bewind.aspx accessed 27-6-2020.

93 Ibid. 9. However, Dutch courts do have the obligation to check whether less intrusive measures than curatorship are possible. See BW, Art. 1:378(1). 
supported or substituted decision-making for persons with intellectual disabilities?

Article 1(1)(e) Wzd defines a 'representative' as a person who is legally authorized to make decisions on behalf of a client. ${ }^{94}$ The phrasing 'on behalf of' means that decisions are made for these clients, instead of with them, indicating a characteristic of substituted decision-making. The role of a representative is further elaborated in Article 3(7) Wzd, which stipulates that representatives should provide the care of a 'good representative'. Unfortunately, the Wzd does not explain what is meant by this term. This is an important omission. According to a report by the Dutch health council (Dutch: Gezondheidsraad), there is no clear set of criteria for good representation in practice. ${ }^{95}$ If there are no guidelines on the matter of good representation, how, then, can we expect representatives to uphold a certain standard of supported decision-making?

Article 3(7) Wzd further stipulates that these representatives should engage the client as much as possible in the fulfilment of his or her tasks. This norm seems to be in accordance with the notion of supported decision-making. Nonetheless, Martin et al. suggest otherwise. These scholars hold the view that Article 12(3) CRPD is not met with a 'mere consideration' of the rights, will and preferences of individuals. Instead, these scholars argue that a stronger phrasing is required which clarifies that respect for the will and preferences constitutes the primary duty of representatives. ${ }^{96}$ When seen in this light, the phrasing 'as much as possible' of the Wzd does not appear as strong and clear-cut as it can be interpreted by representatives in various ways.

Remarkably, the respect for the will and preferences of clients receives more attention in the Wvggz - the Act focused on involuntary treatment for persons with mental disorders. Namely, in Article 2:1(5) Wvggz, it is stated that the will and preferences of clients will be established and taken into account during the preparation, execution, modification and ending of involuntary treatment. In contrast to the Wzd, by not using the words 'as much as possible', the Wvggz obliges representatives to respect the wishes of their clients at all times. This means that under Dutch law, persons with intellectual disabilities have a weaker legal position in this regard than persons with psychological disorders - solely because of the nature of their impairment. This finding is not in line with the obligation of Article 12 in general and Article 12(2) CRPD to recognize persons with disabilities as being equal before the law.

It can be concluded that the Wzd strives to meet Article 12(3) CRPD by assisting persons with intellectual disabilities with decision-making, stating that representatives need to engage their clients in this process as much as possible. Still, within 
this phrasing, the will and preferences of individuals are not described as being determinative. Moreover, this Act describes representatives as persons who make decisions on behalf of individuals with intellectual disabilities. The Wzd therefore does not succeed in putting an end to substituted decision-making.

\subsection{The establishment of safeguards}

The final obligation of Article 12 CRPD that this study will review in relation to the Wzd is provided in paragraph 4. This paragraph stipulates that States Parties should provide for safeguards to prevent abuse in relation to the exercise of legal capacity. More specifically, these safeguards should ensure that support measures in the context of representation are proportional and free of conflict of interest and undue influence. They should also apply within the shortest possible timeframe and be subject to regular review by an impartial body. ${ }^{97}$

\subsubsection{Proportional measures in relation to a person's rights and interests}

In the previous section, it was explained how Tsakyrakis stated that the requirement of 'proportionality' is met when three questions are answered in the affirmative: (1) Is this measure suitable for the achievement of its purpose? (2) Is it necessary to achieve that purpose? (3) Do the benefits of this measure outweigh the possible burden for the individual in question ${ }^{98}$ The purpose of the protective measures that the Wzd sets out is to ensure that persons with intellectual disabilities receive support with decision-making in relation to involuntary care.

It is beyond the scope of this article to examine the proportionality of the Wzd in its entirety. This section therefore focuses on one noteworthy provision in relation to the concept of proportionality. Article 31(1) Wzd states that mayors should provide clients with legal assistance by a lawyer in the case of involuntary placement. This article moves on to describe the right of representatives to deny this legal assistance for his or her client..$^{99}$ Regarding the first and the second question of the proportionality test, it cannot be argued that this stipulation is suitable or necessary for the purpose of supporting persons with decision-making. Here, the balance between the protection of representatives and the legal position of clients is not right. What is the use of denying these clients their right to legal assistance? The explanatory memorandum to the Wzd does not provide an explanation to understand the underlying aim of this regulation. ${ }^{100}$ Moreover, this regulation also sparks many concerns under human rights law, for example in relation to the right to access to justice for persons with disabilities as outlined in Article 13 CRPD. ${ }^{101}$ This protective measure goes beyond what is necessary to support persons with intellectual disabilities with decision-making, leaving them in a weak legal posi-

97 CRPD, 'General Comment No. 1' 5.

98 Tsakyrakis, 'Proportionality' 474.

99 Wzd, Art. 31(1). See also Art. 38(3) and Art. 28aa(7) Wzd.

100 Ministerie van Volksgezondheid, Welzijn en Sport, 'Integrale artikelsgewijze' 50.

101 CRPD, Art. 13. 
tion. It can be concluded that this provision of the Wzd does not meet the proportionality requirement of Article 12(4) CRPD.

\subsubsection{Controlling conflicts of interest and undue influences}

On account of Article 12(4) CRPD, the Netherlands is under the obligation to oversee and control the quality of the interaction between clients, representatives and caregivers. More importantly, it needs to make sure that support measures are free of conflicts of interest and undue influences. The main point of reference in this respect should be the rights, will and preferences of individuals with intellectual disabilities.

A potential conflict of interest may occur as a result of the regulation contained in Article 3(9) Wzd. This article authorizes healthcare providers to appoint a mentor for clients who do not have a representative. ${ }^{102}$ The aim of this provision is to ensure that each person receives the necessary support to make decisions regarding involuntary treatment - including individuals without (engaged) family members. ${ }^{103}$ Several care institutions, however, seem to have used this regulation for their own benefit, as a group of investigative journalists from the platforms Investico, De Groene Amsterdammer, Trouw and De Monitor have revealed. ${ }^{104}$ This study found that these institutions have tried to replace the representatives of clients that were critical of the institutions' position regarding involuntary treatment, in order to appoint representatives that did side with their views. ${ }^{105}$ In other words, this regulation has allowed care institutions to 'silence' the concerns of representatives.

The study by Investico, De Groene Amsterdammer, Trouw and De Monitor also raises another point of concern regarding the role and mandate of representatives. Specifically, the authors explain that the representatives who were appointed by care institutions maintained close ties with these institutions. For example, more than half of these representatives were strongly dependent on these institutions for their income. ${ }^{106}$ How, then, can the impartiality of these representatives be ensured? By failing to address these potential conflicts of interest, the Wzd does not meet this part of the obligation of Article 12(4) CRPD.

\subsubsection{Application for the shortest time possible}

Article 12(4) CRPD also contains a duration requirement, that is, support measures that are connected to the exercise of legal capacity need to apply within the shortest possible timeframe. The Wzd does not contain a provision that deals with the timeframe of these support measures as such. More broadly, under Dutch law, judges have the power to appoint a legal representative for a fixed amount of

102 Wzd, Art. 3(9).

103 Sander Dekker, 'Antwoorden Kamervragen over het bericht dat zorginstellingen misbruik lijken te maken' Ministerie van Justitie en Veiligheid, Directie Wetgeving en Juridische Zaken (10 February 2020) 3.

104 Karlijn Kuijpers and Tim Staal, 'Die man ként onze zoon helemaal niet” De Groene Amsterdammer (Amsterdam, 4 december 2019) www.groene.nl/artikel/die-man-kent-onze-zoon-helemaal-niet accessed 27-6-2020.

105 Ibid.

106 Kuijpers and Staal, 'Die man ként onze zoon helemaal niet' 
time. ${ }^{107}$ Moreover, if a representative holds the view that a less intrusive measure is possible before this time has passed, he or she has the duty to report this. ${ }^{108}$ With respect to legal representation, curators, protective administrators and mentors have the obligation to re-evaluate the necessity of their representation every five years. ${ }^{109}$ Whereas these regulations ensure that representation measures do not have an indefinite duration, the question remains whether they apply for the shortest time possible. Unfortunately, the General Comment does not specify what is meant by this duration requirement. It is therefore not possible to assess whether the Wzd is in compliance with Article 12(4) CRPD in this regard.

\subsubsection{Regular review by an authority or judicial body}

Finally, the last obligation that follows from Article 12(4) CRPD is that States Parties are required to ensure that support measures are subject to regular review by a competent, independent and impartial authority or a judicial body. In the context of legal representation, the Dutch Civil Code meets the requirement of regular review in two ways. First, it contains the requirement of judges to determine whether a mentor or a curator is suitable for a person. ${ }^{110}$ Second, it stipulates that judges need to supervise the legal representation of clients, by examining the annual reports from mentors, protective administrators and curators. ${ }^{111}$ The representation of other representatives such as family members, however, is not subject to judicial review. There are no legal quality requirements for these types of representatives, nor any regular supervision by an authority or legal body. ${ }^{112}$ Still, Article 1(1)(e) Wzd accords family members as much power in terms of decision-making as formal representatives. ${ }^{113}$ This Act should therefore put in place safeguards to ensure that the representation of family members is also subject to regular review.

\section{Conclusion}

In an ideal society, there is a balance between the protection of persons with intellectual disabilities and the respect for their autonomy. This study analyzed the extent to which the Netherlands succeeds in striking this balance, by examining the legal position of persons with intellectual disabilities under the Dutch Care and Coercion Act (Wzd) in light of Article 12 of the CRPD.

The first section explained that until the 1970s, the protection of this group was based on the leading medical model of disability. Over time, this perception has been criticized by many scholars within the field of disability law who argued for a social model of disability. The social model states that disability is not only linked

107 BW, Art. 1:389(1), Art. 1:449(1) and Art. 1:462(1).

108 See, for example, De Rechtspraak, 'Aanbevelingen meerderjarigenbewind' (7 September 2018) 10, De Rechtspraak, 'Richtlijnen voor de curator' (date unknown) 13 and De Rechtspraak, 'Aanbevelingen mentorschap' (2 December 2019) 8.

109 BW, Art. 1:385(2), Art. 1:446a and Art. 1:459(3).

110 Ibid. Art. 1:452(1) and Art. 1:383.

111 Ibid. Art. 1:386(1), Art. 1:455 and Art. 1:459.

112 Gezondheidsraad, 'Goede vertegenwoordiging' 17.

113 Wzd, Art. 1(1)(e). 
to a medical impairment. Rather, attention should be paid to barriers in the environment of individuals and to their individual perception of disability.

The second section showed that the UN Convention on the Rights of Persons with Disabilities (CRPD) strives to remove the barriers in the legal environment of individuals (Art. 12 CRPD). It does so by requiring States Parties to recognize persons with disabilities as persons before the law, to recognize their legal capacity, to provide for support measures for the exercise of this right and to safeguard these support measures and their application.

The third section moved on to relate these legal obligations to the Dutch Care and Coercion Act - abbreviated as the Wzd. The analysis found that the Wzd does not always recognize the legal capacity of persons with intellectual disabilities. This capacity is dependent on a person's mental ability to make a 'reasonable judgement of his or her interests in a certain situation'. This ability may be tested by a medical practitioner who is not involved with a client and who has no knowledge about his or her unique needs. Furthermore, this Act specifies that decisions will be taken 'on behalf of' individuals, failing to explain how representatives can uphold a standard of supported decision-making. Finally, the Wzd inadequately safeguards the support measures of representatives, seeing that they are not always proportional and adequate to prevent conflicts of interests and because representation by family members, in contrast to legal representatives, is not legally reviewed on a regular basis. Overall, the legal position of persons with intellectual disabilities does not meet the standards of Article 12 CRPD in these cases.

What is the theoretical implication of these findings? Does the underlying perspective of the Wzd lean more towards the medical model or the social model? In the Wzd, an imbalance between the protection of and the respect for the autonomy of persons with intellectual disabilities can be observed. According to this Act, persons with intellectual disabilities are perceived as vulnerable individuals who are in need of strong support. This can for example be illustrated by the fact that representatives are able to deny legal assistance to this group in the case of involuntary placement. Viewed in light of the social model, this Act insufficiently removes the barriers in the legal environment of persons. The challenge now is to bring the Wzd back into balance. For that purpose, the following section will outline several recommendations.

It is important to recognize that this study is subject to limitations. First, it did not match the stipulations of the Wzd against reality considering that this Act only entered into force very recently. For that reason, this study cannot incorporate evaluations of the Wzd by persons with intellectual disabilities and by those directly involved. In addition, this study did not elaborate on the practical usefulness of the human rights norms of Article 12 CRPD for individuals working with this group. If the debate is to be moved forward, further work is needed to examine how this article can be translated into an applied, workable guideline for practitioners. Further research in this field would be of great help in realizing the proposed paradigm shift of Article 12 CRPD, in which persons with disabilities are seen as subjects of rights, rather than as objects of pity. In the literature, scholars have de- 
scribed this shift as 'disorienting, uncomfortable, even frightening'. ${ }^{114}$ Yet there is hope. As Herman Melville wrote in his novel Moby Dick: 'ignorance is the parent of fear'. ${ }^{115}$ Awareness of this issue is therefore the first step to achieve equality for all individuals - disabled or not.

\subsection{Recommendations}

This section proposes several recommendations to Dutch policymakers to ensure greater alignment with Article 12 CRPD. After highlighting a number of legislative recommendations, it will describe three policy recommendations.

Concerning Article 12(2) CRPD, it is recommended to:

- Formulate clearly in the Wzd that all clients have the right to legal capacity. Make clear that this right is not dependent on the mental capacity of these individuals.

- Provide an explanation of the term 'mental capacity' in the Wzd in order to combat subjective, diverging interpretations of this term.

- Stipulate in Article 3(2) Wzd that the mental capacity of persons can only be assessed by persons who know the specific particularities of clients, as opposed to a medical practitioner who is not affiliated with a client.

Concerning Article 12(3) CRPD, it is recommended to:

- Clarify in Article 3(2) Wzd that a person only acts as a representative to support a client with decision-making when it is determined that he or she is mentally incapacitated.

- Replace the phrasing 'on behalf of' in Article 1(1)(e) Wzd with 'together with clients, respecting their will and preferences at all times'.

- Formulate clearly what constitutes 'good representation' and consult persons with intellectual disabilities for this definition.

- Stipulate the obligation of courts to determine in each case whether less intrusive alternatives to legal representation are available for clients in need of support. ${ }^{116}$

Concerning Article 12(4) CRPD, it is recommended to:

- Describe in Article 3(7) Wzd that representatives have the duty to take the will and preferences of individuals into consideration.

- Change Article 28aa(7), Article 31(1) and Article 38(3) Wzd to ensure that representatives cannot deny legal assistance by a lawyer for their clients in the case of involuntary placement. ${ }^{117}$

- Establish safeguards to prevent the misuse of Article 3(9) Wzd by care institutions.

- Create a provision in the Wzd which specifies how conflicts between clients, representatives and care institutions can be mediated.

114 Booth Glen, 'Changing Paradigms' 162. See also Gooding, ‘Querying the call' 265.

115 Herman Melville, Moby Dick (Richard Bentley, 1851) 26.

116 This obligation is already laid down in relation to curatorship. See BW, Art. 1:378(1). However, courts are not yet obliged to make this assessment when appointing a mentor or a protective administrator.

117 Reference can be made to Art 1:7 of the Wvggz in this respect. 
- Establish legal requirements for family members acting as representatives to persons with intellectual disabilities and ensure that this type of representation is subject to regular legal review.

The policy recommendations are as follows:

- Put an end to the regime of curatorship and encourage judges to make use of the combination of protective administration and mentorship for the representation of clients.

- Develop a mandatory training course for persons who want to become a (legal) representative in which quality standards for supported decision-making are provided.

- Develop a training on the perspective of the CRPD and Article 12 of this Convention in particular for persons working with persons with intellectual disabilities at the governmental, regional and local level.

\section{Bibliography}

\section{Treaties}

Convention on the Rights of the Child (adopted 20 November 1989, entered into force 2 September 1990) 1577 UNTS 3 (CRC)

Convention on the Rights of Persons with Disabilities (adopted 13 December 2006, entered into force 3 May 2008) 61 UNTS 106 (CRPD)

\section{UN Documents}

United Nations Economic and Social Council, 'Report of the Special Rapporteur on the right of everyone to the enjoyment of the highest attainable standard of physical and mental health, Paul Hunt' (11 February 2005) E/CN.4/2005/51

United Nations Department of Economic and Social Affairs, 'Handbook for parliamentarians' (2007) http://archive.ipu.org/PDF/publications/disabilities-e.pdf accessed 29-6-2020

United Nations Human Rights Council, 'Interim report of the Special Rapporteur on torture and other cruel, inhuman or degrading treatment or punishment' (28 July 2008) A/63/175

UN Committee on the Rights of Persons with Disabilities, 'Concluding Observations on Peru' CRPD/C/PER/CO/1 (20 April 2012)

United Nations Human Rights Council, 'Report of the Special Rapporteur on torture and other cruel, inhuman or degrading treatment or punishment, Juan E. Méndez' (1 February 2013) A/HRC/22/53 
United Nations Committee on the Rights of Persons with Disabilities, 'Concluding Observations of the Committee on the Rights of Persons with Disabilities (Australia)' (2 September 2013) CRPD/C/AUS/CO/1

UN Committee on the Rights of Persons with Disabilities (CRPD), 'General Comment No. 1: Article 12: Equal recognition before the law' (19 May 2014) CRPD/C/ $\mathrm{GC} / 1$

UN Committee on the Rights of Persons with Disabilities, 'Guidelines on the right to liberty and security of persons with disabilities' (17 August 2015) 14th session

\section{Dutch legislation}

Burgerlijk Wetboek (BW) 1 January 1992 (Civil Code)

Besluit Kwaliteitseisen CBM 1 June 2015 (CBM Quality Requirements Decree)

Wet verplichte geestelijke gezondheidszorg (Wvggz) 1 January 2020 (Compulsory Mental Health Act)

Wet zorg en dwang psychogeriatrische en verstandelijke gehandicapte cliënten (Wzd) 1 January 2020 (Care and Compulsion Act)

\section{Official publications}

Dekker S., 'Antwoorden Kamervragen over het bericht dat zorginstellingen misbruik lijken te maken' Ministerie van Justitie en Veiligheid, Directie Wetgeving en Juridische Zaken (10 February 2020)

Eerste Kamer der Staten-Generaal, 'Brief van de staatssecretaris van volksgezondheid, welzijn en sport. Regels ten aanzien van zorg en dwang voor personen met een psychogeriatrische aandoening of een verstandelijke handicap (Wet zorg en dwang psychogeriatrische en verstandelijk gehandicapte cliënten)' (5 October 2013) 31996

De Jonge H., 'Reactie van de minister over het advies “Goede vertegenwoordiging”" Ministerie van Volksgezondheid, Welzijn en Sport (1 July 2019)

Ministerie van Volksgezondheid, Welzijn en Sport, 'Integrale artikelsgewijze toelichting Wet zorg en dwang' (date unknown)

Parliamentary papers (Dutch: Kamerstukken) 2010/2011, 31996

Tweede Kamer der Staten-Generaal, 'Regels ten aanzien van zorg en dwang voor personen met een psychogeriatrische aandoening of een verstandelijke handicap (Wet zorg en dwang psychogeriatrische en verstandelijk gehandicapte cliënten); Memorie van toelichting' (10 July 2009) 31996

\section{Books and edited volumes}


Arneil B. \& Hirschmann H.J., Disability and political theory (Cambridge University Press, 2016)

Barry B.M., Justice as impartiality (New York: Oxford University Press, 1995)

Brems E, Desmet E. \& Vandenhole W. (eds.), Children's Rights Law in the Global Human Rights Landscape: Isolation, Inspiration, Integration? (Taylor \& Francis, 2017)

Cohen G.A., Self-ownership, freedom, and equality (Cambridge University Press, 1995)

Degener T., 'Challenges and Compliance of the UN CRPD', in Dotorthy Estrada-Tanck (ed.), Human Rights of Persons with Disabilities in International and EU Law (AEL Working Papers 2016)

Kanter A.S., The development of disability rights under international law: From charity to human rights (Routledge, 2014)

Kittay E.F., Love's labor. Essays on women, equality and dependency (Routledge, 1999)

Melville H., Moby Dick (Richard Bentley, 1851)

Nussbaum M., Frontiers of justice. Disability, nationality, species membership (Cambridge: Belknap Press, 2006)

Rawls J., Political liberalism (Columbia University Press, 1993)

Riddle C.A., Disability and justice: The capabilities approach in practice (Lexington Books, 2014)

Series L. \& Nilsson A., 'Article 12 CRPD: Equal Recognition before the Law' in Ilias Bantekas M.A.S. \& Anastasiou D. (eds.), The UN Convention on the Rights of Persons with Disabilities: A Commentary (Oxford University Press, 2018)

\section{Academic papers in periodicals}

Arstein-Kerslake A. \& Flynn E., 'The General Comment on Article 12 of the Convention on the Rights of Persons with Disabilities: A roadmap for equality before the law' (2016), 20(4) The International Journal of Human Rights

Baffoe M., 'Stigma, discrimination \& marginalization: Gateways to oppression of persons with disabilities in Ghana, West Africa' (2013) 3(1) Journal of Educational and Social Research

Barclay L., 'Disability, Respect and Justice' (2010) 27(2) Journal of Applied Philosophy

De Bhailís C. \& Flynn E., 'Recognising legal capacity: commentary and analysis of Article 12 CRPD' (2017) 13(1) International Journal of Law in Context 
Booth Glen K., 'Changing Paradigms: Mental Capacity, Legal Capacity Guardianship, and Beyond' (2012) 44 Colum Hum Rts L Rev

Brighouse H., 'Can Justice as Fairness Accommodate the Disabled?' (2001) 27(4) Social Theory and Practice

Broer J. et al., 'Stijging van BOPZ-maatregelen en dwangopnames in de GGZ' (2018) 162(49) Nederlands Tijdschrift voor Geneeskunde

Degener T., 'A human rights model of disability' (2014) Disability social rights

Degener T., 'Disability in a human rights context' (2016) Laws

Dhanda A., 'Legal capacity in the disability rights convention: stranglehold of the past or lodestar for the future' (2006) 34 Syracuse J. Int'l L. \& Com.

Dinerstein R., 'Implementing legal capacity under article 12 of the UN convention on the rights of persons with disabilities: the difficult road from guardianship to supported decision-making' (2012) 19(2) Human Rights Brief

Frederiks B., 'Commentary on "Implementation of policy regarding restrictive practices in England”' (2020) 25(1) Tizard Learning Disability Review

Flynn E. \& Arstein-Kerslake A., 'Legislating personhood: Realising the right to support in exercising legal capacity' (2014) 10(1) International Journal of Law in Context

Gómez P. et al., 'Psychosocial Disability and Deprivation of Liberty: Reviewing the case of Qatar in the light of the Convention on the Rights of Persons with Disabilities' (2018) 24 International Journal of Mental Health and Capacity Law

Gooding P. \& Flynn E., 'Querying the call to introduce mental capacity testing to mental health law: Does the doctrine of necessity provide an alternative?' (2015) 4(2) Laws

Gooding P., 'Navigating the 'flashing amber lights' of the right to legal capacity in the united nations convention on the rights of persons with disabilities: Responding to major concerns' (2015) 15(1) Human Rights Law Review

Griffo G., 'Models of disability, ideas of justice, and the challenge of full participation' (2014) 19(2) Modern Italy

Harnacke C., 'Disability and capability: exploring the usefulness of Martha Nussbaum's capabilities approach for the UN Disability Rights Convention' (2013) 41(4) The Journal of Law, Medicine \& Ethics

Keene A.R. et al., 'Taking capacity seriously? Ten years of mental capacity disputes before England's Court of Protection' (2019) 62 International journal of law and psychiatry 
McSherry B., 'Protecting the Integrity of the Person: Developing Limitations on Involuntary Treatment' (2008) 26 Law Context: A Socio-Legal J.

Minkowitz T., 'The United Nations Convention on the Rights of Persons with Disabilities and the Right to Be Free from Nonconsensual Psychiatric Interventions' (2007) 34 Syracuse J. Int'l L. \& Com.

Mitra S., 'The capability approach and disability' (2006) 16(4) Journal of disability policy studies

Moonen X.M.H. et al., 'Het beoordelen van wilsbekwaamheid bij minderjarigen in de leeftijd van 12-18 jaar met een lichte verstandelijke beperking in een OBC: een verkenning' (2013) 39(4) NTZ

Rawls J., 'A Kantian Concept of Equality' (1975) Cambridge Review

Rawls J., 'Justice as Fairness: Political Not Metaphysical' (1985) 14 PHIL. \& PUB. AFF.

Stelma-Roorda R., Blankman K. \& Antokolskaia M V, 'A changing paradigm of protection of vulnerable adults and its implications for the Netherlands' (2019) Family \& Law

Terzi L., 'Beyond the dilemma of difference: The capability approach to disability and special educational needs' (2005) 29(3) Journal of Philosophy of Education

Tromel S., 'A personal perspective on the drafting history of the United Nations Convention on the Rights of Persons with Disabilities' (2009) 1 Eur. YB Disability L.

Tsakyrakis S., 'Proportionality: An assault on human rights?' (2009) 7(3) International Journal of Constitutional Law

Ward T. \& Stewart C., 'Putting human rights into practice with people with an intellectual disability’ (2008) 20(3) Journal of Developmental and Physical Disabilities

Winick B.J., 'The Side Effects of Incompetency Labeling and the Implications for Mental Health' (1995) 1(1) PSYCH. PUB. POL'Y \& L.

Zahraa M., 'The Legal Capacity of Women in Islamic Law' (1996) 11 Arab L.Q.

\section{Government documents}

Blankman K. et al., 'Mentorschap in Perspectief' Ministerie van Volksgezondheid, Welzijn en Sport (2007)

De Boer M. et al., 'Belevingsonderzoek dwang in de zorg: twee samenhangende deelstudies' (2015), Ministerie voor Volksgezondheid, Welzijn en Sport van de Camp L. et al., 'Wet Zorg en Dwang, Inzichten uit de pilots en droogoefensessies', Ministerie van Volksgezondheid, Welzijn en Sport (2019) 
Wetenschappelijk Onderzoek- en Documentatiecentrum (WODC), 'Werking Wet wijziging curatele, beschermingsbewind en mentorschap, Besluit kwaliteitseisen cbm en Regeling beloning cbm' (2018)

\section{Reports by organizations}

Alliantie VN-verdrag Handicap, 'Schaduwrapportage Verdrag inzake de rechten van personen met een handicap in Nederland' (2019), https://iederin.nl/wpcontent/uploads/2019/12/Schaduwrapport-VN-verdrag-Handicap.pdf (accessed 22-6-2020)

Bach M. \& Kerzner L., 'A new paradigm for protecting autonomy and the right to legal capacity' (2014), The Law Commission of Ontario http://repositoriocdpd. net: $8080 /$ bitstrea m/handle/123456789/449/L_B a ch M _ NewParadigmAutonomy_2010.pdf?sequence=1 (accessed 22-6-2020)

Blankman K. \& Vermariën K., 'Conformiteit van het VN-Verdrag inzake de rechten van personen met een handicap en het EVRM met de huidige en voorgestelde wetgeving inzake vertegenwoordiging van wilsonbekwame personen in Nederland' (2015), College voor de Rechten van de Mens

Council of Europe, 'Who Gets to Decide? Right to Legal Capacity for Persons with Intellectual and Psychosocial Disabilities' (2012), CommDH Issue Paper

Gezondheidsraad, 'Goede vertegenwoordiging' 8 (2019)

Kjaerum M., 'Involuntary placement and involuntary treatment of persons with mental health problems', European Agency for Fundamental Rights (Luxembourg, 2012)

Martin W. et al., 'The Essex Autonomy Project. Three Jurisdictions Report. Towards Compliance with CRPD Art. 12 in Capacity/Incapacity legislation across the UK' (2016) University of Essex 48-50. https://autonomy.essex.ac.uk/wp-content/ uploads/2017/01/EAP-3J-Final-Report-2016.pdf (accessed 22-6-2020)

Minkowitz T., 'Recognizing forced and coerced psychiatric interventions against women, men and children as a harmful cultural practice' (2014), Center for the Human Rights of Users and Survivors of Psychiatry, Submission for Joint CEDAW-CRC General Recommendation/General Comment on Harmful Practices

Minkowitz T., 'Why Mental Health Laws Contravene the CRPD - An Application of Article 14 with Implications for the Obligations of States Parties' (2011), Center for the Human Rights of Users and Survivors of Psychiatry

Nederlandse Vereniging van Artsen voor Verstandelijk Gehandicapten (NVAVG), 'Medische beslissingen rond het levenseinde bij mensen met een verstandelijke beperking' (2007), https://nvavg.nl/wp-content/uploads/2014/upload/standaarden/ medische-beslissingen-rond-het-levenseinde---def.pdf (accessed 27-6-2020) 
De Rechtspraak, 'Weer meer mensen onder bewind' (2017), www.rechtspraak.nl/ Organisatie-en-contact/Organisatie/Raad-voor-de-rechtspraak/Nieuws/Paginas/ Weer-meer-mensen-onder-bewind.aspx (accessed 27-6-2020)

De Rechtspraak, 'Aanbevelingen meerderjarigenbewind' (7 September 2018)

De Rechtspraak, 'Richtlijnen voor de curator' (date unknown)

De Rechtspraak, 'Aanbevelingen mentorschap' (2 December 2019)

\section{Newspaper articles}

Boshuizen E., 'Verstandelijk beperkte Tamara zat onterecht opgesloten in zorginstelling Philadelphia', Noord-Holland Nieuws (Amsterdam, 6 December 2016), www. nhnieuws.nl/nieuws/196598/verstandelijk-beperkte-tamara-zat-onterechtopgesloten-in-zorginstelling-philadelphia (accessed 17-2-2020)

Editorial office Skipr, 'Snelste stijging aantal dwangmaatregelen ggz in 10 jaar', Skipr (Houten, 3 February 2020), www.skipr.nl/nieuws/snelste-stijging-aantaldwangmaatregelen-ggz-in-10-jaar/ (accessed 17-6-2020)

Frederiks B., 'Brandon is meer dan een gevaar', Medisch Contact (Utrecht, 2 March 2011), www.medischcontact.nl/nieuws/laatste-nieuws/artikel/brandonis-meer-dan-een-gevaar.htm (accessed 17-6-2020)

Kuijpers K. \& Staal T., 'Die man ként onze zoon helemaal niet', De Groene Amsterdammer (Amsterdam, 4 december 2019), www.groene.nl/artikel/die-man-kentonze-zoon-helemaal-niet (accessed 27-6-2020)

Sitalsing K., 'Dertig jaar na Jolanda Venema kan er zoveel meer dan de vrijheid beperken', Trouw (Amsterdam, 12 March 2019), www.trouw.nl/nieuws/dertigja ar-na-jolanda-venema-kan-er-zoveel-meer-dan-de-vrijheidbeperken b6db964a/ (accessed 17-6-2020) 